\title{
The Impact of Place of Origin to the Language Expression
}

\author{
Masda Surti Simatupang ${ }^{1}$, Ramot Peter $^{2}$, Erni Murniarti ${ }^{3}$ \\ ${ }^{l}$ English Department Faculty of Letters, Universitas Kristen Indonesia, Jln. Mayjen Sutoyo 2 Cawang, Jakarta, \\ Indonesia \\ ${ }^{2}$ Charcter Building Development Centre, Information System Department, School of Information System, Bina \\ Nusantara University, Jakarta, Indonesia \\ ${ }^{3}$ Graduate Program of Education Administration, Universitas Kristen Indonesia, Jln. Mayjen Sutoyo 2 Cawang, \\ Jakarta, Indonesia \\ masdasimatupang@uki.ac.id ${ }^{1}$, ramot.peter@binus.ac.id²,
}

\begin{abstract}
Language and culture variety is a part of our life and as a characteristic of our life. The variety occurs due to the diversity of geography and language development in our community. Language dialect differences from the view of geography or place of origin can be observed from the local language used in that areas which are influenced by the cultures surrounding it. Informal Indonesian language spoken in different places will be practiced differently in terms of pronunciation, vocabulary, and intonation. This study is qualitative research to explore the impact of place of origin to the varieties of informal Indonesian language expression of Indonesian people, specifically the students who study at Christian University of Indonesia. The differences are viewed from the language and culture they have at their home town that contribute to their language use in campus life. The sample consists of eight students from four place of origin: Ambon, Jakarta, Medan, and Palembang. They are given the questionnaires about their informal Indonesian spoken in their home town, then they are interviewed to have deeper information concerning the topic. The results showed different pronunciation and vocabulary choices in those places. The positive impact of the differences is that we are proud of cultural diversity exist in our country. It contributes to cultural diversity that Indonesia is multilingual and multicultural country. The negative impact of the differences is that differences can lead to conflict if we do not accept diversity. Conflict can lead to hostilities among different groups of societies.
\end{abstract}

Keywords: Language and culture, Language diversity, Language expression, Place of origin

\section{INTRODUCTION}

Language diversity cannot be separated from cultural diversity since both are related to each other. Therefore, the elaboration of language diversity and cultural diversity is discussed simultaneously in this study. When deliberating language diversity, we unavoidable discuss cultural diversity as Jiang (2000) and Brown (2000) proved that language and culture exist concurrently. In other words, our language is influenced a lot by our culture together with the ethnic language grow together unseparable. Vernacular languages in every region in Indonesia are protected by our government due to the fact that they valued the cultures as sources of national development (Dharma, 2011). Culture, the knowledge that we get from our society or something that we understand from our own place of origin, can also be defined as 'socially acquired knowledge' (Alptekin, 1993). The way we speak or write typically affected by the culture that we are raised in.

The research questions of this study concern fistly, how informal Indonesia language is used differently in Ambon, Jakarta, Medan, and Palembang, and secondly, how the vocabulary is used differently in Ambon, Jakarta, Medan, and Palembang; and thirdly, what are the effects of the differences.

The study of language diversity deals with wide range of language diversity. For scope and limitation, this study constrains pronunciation diversity of word(s), different choices of words among Bahasa, and some expressions dealing with daily words and expressions. 


\section{LANGUAGE DIVERSITY}

Language diversity occurs naturally which means that freedom and nature take parts. For example, the sounds of animals (onomatopoeia) like a dog in English have some variation: barking 'woof' or 'ruff'; angry dogs 'growl'; scary dogs 'whimper'; specific sound like a wolf 'howl'; large dogs 'bow-wow'; small dog 'yip' or 'yap'. In Indonesian, we only have limited sounds of barking dog: 'menggonggong' or 'menyalak'; the scary dog 'melolong'; small dog 'mengaing'. The sound of the barking dogs but different languages create different sounds.

Another illustration of language diversity is the different numbers of words referering to the same referent of different groups of society. For instance, the word 'rice' in English can be expressed in four different words: padi (rice as a growing crop or when harvested but not yet milled), gabah (unhulled paddy), beras (uncooked rice), nasi (ready to eat rice). Furthermore, Indonesian language has other terms dealing with rice since it is our staple food: bubur nasi (rice porridge), lontong (rice wrapping in banana's leaf, steaming on boiling water for about five hours), ketupat (rice wrapping in young coconut's leaf, steaming for four to six hours in boiling water), and buras (rice mixed with dessicated coconut, wrapping in banana's leaf, steaming on boiling water mixed with coconut milk for four to six hours) (Rohmitriasih, 2018).

Religion is another thing which influence language diversity. The muslims, for instance, speak informal Indonesian language with a lot of Arabic vocabulary in their conversation since the koran as their holy book using Arabic language and the Muslims still use the koran in Arabic language until now. The Arabic words which are familiar to be used in daily speaking are sholat (praying), tarawih (praying at night in Ramadhan month), hadits (a report of the saying or action of Muhammad or his companions, together with the tradition of its chain of transmission), etc. The Christians, on the other hand, used words correlate to words used in the Bible which is influenced from Hebrew and Greek. Some vocabulary which mostly appear on their conversation or praying includes alleluia (halelujah), shalom (greeting) and alaihim (peace be upon you).

In Indonesia, people use Indonesian language or bahasa as a national language that unites people so that they are able to communicate whithin different ethnic languages and cultures. In different places, however, there will also be variaties or different dialects in pronunciation, and choices of words that vary from one place to another. These variations will enrich informal
Indonesian varieties and should not be considered as a threat since they give variations to informal Indonesian language

This study relates to language diversity concerning different dialects, intonation, pronunciation, choices of words (diction), and vocabulary. This study deals with language diversity of informal Indonesian among four different places of origin, which are influenced mostly by the vernacular language surrounding that place. The informal Indonesian language which is spoken in those four places has differences and similarities as well. Those differences will be elaborated entirely in this research.

\section{METHOD}

This research aims at explaining difference expression in Indonesian language of similar meaning based on four different place of origin: Ambon, Jakarta, Medan and Palembang. The participants are eight young adults between 19-25 years of age from those four different places of origin or ethnic groups. Two of them speak Ambon, two speak Betawi language spoken in Jakarta city, two speak Medan dialect of informal Indonesian, and the last two speak Palembang language as a part of informal Indonesian. They are delivered questions via google drive regarding vocabulary and some expressions which are commonly used in their places of origin. After that, they are interviewed to know deeper about the dialects they speak. As the user of the dialects, they lived in their home town from birth until junior or high school and moved to Jakarta to continue their studies and to work. For them, it is a blessing that Indonesia has many distinctive dialects that enrich the languages and cultures in Indonesia. In Jakarta, they adopt the vocabulary and pronunciation, so that they do not speak based on their dialects, but Betawi dialect spoken in Jakarta.

The data were analysed descriptively to get the picture of different language expression used in the four different places in Indonesia. This is qualitative research that the data were analysed systematically, factually, and accurately against facts and phenomena (Nasir 2005, Creswell, 2007). The data were taken from the answers provided by the respondents, then were classified into: pronouns, nouns, verbs, and other class words. Furthermore, in the discussion the writers elaborate the diverse usage of the four dialects and explain how they differ. In the last explanation, the writers describe the impacts of the diversities. 


\section{RESULTS AND DISCUSSION}

Data which were taken from the participants are divided into four classifications: pronouns, nouns, verbs, and other word classes. They will be analysed into unique expression, pronunciation, and vocabulary.

Table 1. Pronoun

\begin{tabular}{|l|l|l|l|l|l|}
\hline $\begin{array}{l}\text { Inform } \\
\text { al Indo } \\
\text { nesian }\end{array}$ & Ambon & $\begin{array}{l}\text { Jakar } \\
\text { ta }\end{array}$ & Medan & $\begin{array}{l}\text { Palem } \\
\text { bang }\end{array}$ & $\begin{array}{l}\text { Eng } \\
\text { lish }\end{array}$ \\
\hline aku & beta & gue & awak & aku & I \\
\hline $\begin{array}{l}\text { kamu, } \\
\text { kau }\end{array}$ & $\begin{array}{l}\text { ose, } \\
\text { ale }\end{array}$ & $\begin{array}{l}\text { elo, } \\
\text { ente }\end{array}$ & $\begin{array}{l}\text { kau, } \\
\text { kam }\end{array}$ & awak & you \\
\hline kalian & $\begin{array}{l}\text { ose } \\
\text { samua }\end{array}$ & $\begin{array}{l}\text { elo } \\
\text { pade }\end{array}$ & klen & kamu & $\begin{array}{l}\text { you } \\
(\mathrm{pl})\end{array}$ \\
\hline dia & dia & $\begin{array}{l}\text { die } \\
\text { dia }\end{array}$ & $\begin{array}{l}\text { dio } \\
\text { she }\end{array}$ \\
\hline kita & katong & kite & kita & kito & we \\
\hline $\begin{array}{l}\text { merek } \\
\text { a }\end{array}$ & $\begin{array}{l}\text { ka } \\
\text { morang }\end{array}$ & $\begin{array}{l}\text { mere } \\
\text { ka }\end{array}$ & mereka & $\begin{array}{l}\text { wong- } \\
\text { wong } \\
\text { itu }\end{array}$ & they \\
\hline
\end{tabular}

\section{Vocabulary Differences}

For the pronoun 'I', ' $a k u$ ' as informal Indonesian is understood all over Indonesian. In this research, however, people prefer to use different word from informal Indonesian. The unique expression is using 'awak' in Medan which means 'I', but in Palembang 'you' (see table 1). This can cause misunderstanding or conflict if the speaker and hearer from Palembang and Medan do a conversation using the word 'awak' without recognizing the difference. For instance: "Awaklah yang pergi” ('awak' will go). Who will go, I or you?

Pronoun 'you' (plural) in Palembang is 'kamu' which is known as you (singular) in Bahasa Indonesia. Since the meaning is the same (you), difference is only in number (singular or plural), so mostly it does not a trigger of misunderstanding. For example:

1. "Кати bedua bae yang masak sayurnyo." (Both of you cook the vegetables).

2. "Kamu galo datang, yo?" (all of you come, please).

Data from table 2 show the vocabulary differences in those four different places. The distinctive words are used mostly in Medan. 'Mobil' (car) in Medan is called motor, where in other places it refers to a motor bike. 'Motor' (motor bike) is called kereta, where in other places it refers to a train. 'Jalan' (street) is called pasar, where in other places it refers to a market. 'Pasar' (market) is called pajak, where in other places it refers to a tax. So, Indonesian people should be aware if they visit Medan or move to Medan. Knowing words meaning differently in different place will avoid misunderstanding.

Table 2. Nouns

\begin{tabular}{|l|l|l|l|l|l|}
\hline $\begin{array}{l}\text { Inform } \\
\text { al Indo } \\
\text { nesian }\end{array}$ & $\begin{array}{l}\text { Am } \\
\text { bon }\end{array}$ & $\begin{array}{l}\text { Jakar } \\
\text { ta }\end{array}$ & Medan & $\begin{array}{l}\text { Palem } \\
\text { bang }\end{array}$ & $\begin{array}{l}\text { Eng } \\
\text { lish }\end{array}$ \\
\hline anak & ana & anak & anak & budak & child \\
\hline mobil & oto & mobil & motor & mobil & car \\
\hline motor & motor & motor & kereta & motor & $\begin{array}{l}\text { motor } \\
\text { bike }\end{array}$ \\
\hline angkot & oto & angkot & $\begin{array}{l}\text { suda } \\
\text { ko }\end{array}$ & $\begin{array}{l}\text { taksi, } \\
\text { angkot }\end{array}$ & $\begin{array}{l}\text { mini } \\
\text { shuttle }\end{array}$ \\
\hline jalan & jalan & jalan & pasar & jalan & street \\
\hline pasar & pasar & pasar & pajak & pasar & market \\
\hline duit & kepeng & duit & duit & duit & money \\
\hline garpu & forok & garpu & garpu & garpu & fork \\
\hline telur & talor & telor & telor & telok & egg \\
\hline kepala & pala & pala & pala & pala & head \\
\hline ikan & ikang & ikan & ikan & iwak & fish \\
\hline orang & orang & orang & orang & wong & person \\
\hline
\end{tabular}

In Palembang, there are words which are different from other places, for example, 'anak' (child) is called budak, where in other places it refers to a slave. Angkot, shortened word from angkutan kota (public transportation like mini shuttle) is called taxi, which refers to different type of transportation in other places. Other different terms spoken in Palembang are ikan (fish), which is called iwak; orang (person, people) which is called wong, and ikut (follow), which is called melok. The words iwak, wong and melok are originated from Javaness language. This is because many people from Java island live in Palembang (Sumatera island), see table 2. So, the variation of informal Indonesian language can be derived from vernacular languages existing in Indonesia.

In Ambon, the word which is very far different from other places is kepeng (money), where in other places 'duit' is generally used. Matikan HP (switch of the hand phone /HP) is called bunuh HP, where in other places it means kill HP. It sounds strange to say bunuh HP since the word bunuh has a connotation of killing people (see table 3). Still in Ambon, there are words influenced by the Dutch colony which are survived until now because many people speak the words that become their habit although they do not belong to informal Indonesian words. For example, 'garpu' (fork) is called forok. Other examples are dangke (thanks), gutten morgen (good morning), and eet smakelijk (have a nice eating). 
In all places, 'kepala' (head) is called 'pala', the shorten of kepala. This is the only similar word used in all places. 'Telur' (egg) in all places employs the variation of telur: talor, telor, telok, which is easy to guess.

Table 3. Verbs

\begin{tabular}{|l|l|l|l|l|l|}
\hline $\begin{array}{c}\text { Inform } \\
\text { al } \\
\begin{array}{c}\text { Indone } \\
\text { sian }\end{array}\end{array}$ & Ambon & Betawi & Medan & $\begin{array}{l}\text { Palem } \\
\text { bang }\end{array}$ & $\begin{array}{l}\text { Eng } \\
\text { lish }\end{array}$ \\
\hline makan & makang & makan & makan & makan & eat \\
\hline tidur & $\begin{array}{l}\text { tidor, } \\
\text { sono }\end{array}$ & tidur & tidur & tiduk & sleep \\
\hline kerja & karja & kerje & kerja & $\begin{array}{l}\text { begaw } \\
\text { e }\end{array}$ & work \\
\hline pergi & pigi & pergi & pigi & pegi & go \\
\hline $\begin{array}{l}\text { jalan- } \\
\text { jalan }\end{array}$ & baronda & jalan- & jalan- & jalan- & $\begin{array}{l}\text { walk } \\
\text { aroun } \\
\text { jalan }\end{array}$ \\
\hline punya & pung & punye & punya & punyo & have \\
\hline $\begin{array}{l}\text { ingat } \\
\text { inga }\end{array}$ & ingat & ingat & inget & $\begin{array}{l}\text { re } \\
\text { mem } \\
\text { ber }\end{array}$ \\
\hline $\begin{array}{l}\text { ikut } \\
\text { bikin }\end{array}$ & biking & bikin & bikin & bikin & $\begin{array}{l}\text { make } \\
\text { low }\end{array}$ \\
\hline $\begin{array}{c}\text { matika } \\
\text { n HP }\end{array}$ & $\begin{array}{l}\text { bunuh } \\
\text { HP }\end{array}$ & matikan & matika & matike & $\begin{array}{l}\text { switc } \\
\text { h HP } \\
\text { HP } \\
\text { HP }\end{array}$ \\
\hline
\end{tabular}

Table 4. Adjective and other class words

\begin{tabular}{|l|l|l|l|l|l|}
\hline $\begin{array}{l}\text { Informal } \\
\text { Indo } \\
\text { nesian }\end{array}$ & Ambon & Jakarta & Medan & $\begin{array}{l}\text { Palem- } \\
\text { bang }\end{array}$ & English \\
\hline sudah & su & udeh & udah & dah & already \\
\hline lagi & lai & lagi & lagi & lagi & again \\
\hline jangan & jang & jangan & jangan & jangan & don't \\
\hline tidak & seng & $\begin{array}{l}\text { gak, } \\
\text { enggak }\end{array}$ & $\begin{array}{l}\text { Tidak, } \\
\text { engga } \\
\text { k }\end{array}$ & idak & not \\
\hline
\end{tabular}

\section{Pronunciation and Spelling Differences}

In most parts of Indonesian, the spelling and pronunciation are mostly written and pronounced exactly the same. Spelling and pronunciation of a great deal of Jakarta's words are usually written with ending -e like the pronoun 'dia' (he, she, her) in informal Indonesia become die /die/ and the pronoun kita (we, us) becomes kite /kite/. On the other hand, Palembang's words are written with ending -o like the pronoun dio (he, she) and kito (we, us). Nevertheless, we cannot generalize that the ending will always be like that. The pronoun 'mereka' (they) will never be changed to mereke or mereko. Therefore, we must be careful which words can be changed for the ending -a in informal Indonesian to Jakarta -e ending or Palembang's -o ending.

Compared to other places, Palembang has distinctive pronunciation.

1. The $/ \mathrm{r} / \mathrm{silent}$ in the middle of words, for example pergi (go) becomes pegi /pdgi/; berdoa becomes bedoa /bddoa/; bergerak (move) becomes begerak /bagdrak/.

2. Change pronounciation of the final sound $/ \mathrm{N}$ becomes /o/, for example dia (she, he) becomes dio /dio/; kita (we) becomes kito; sama becomes samo; lama becomes lamo. However, not all the last $/ N$ becomes /o/. For example kepala (head) does not pronounced palo $/ \mathrm{o} /$, but remain the same pala $/ \mathrm{N}$.

3. Change pronounciation of the final sound $/ \mathrm{r} /$ becomes $/ \mathrm{k} /$, for example tidur (sleep) becomes tiduk; besar (big) becomes besak; telor becomes telok. Nontheless, kasar (rude) is pronounced /kasar/. It does not become kasak, or pasar does not become /pasak/.

4. Change pronounciation of the final sound $/ \wedge \mathrm{r} /$ becomes $/ \mathrm{o} /$, for example ular /-^r/ (snake) becomes ulo /-o/; But other final sound $/-\wedge \mathrm{r} /$ remain the same spelling and pronunciation, for instance, bakar (burn), kabar (news), sabar (patient), akar (root).

5. Change pronounciation of the final sound $/ \wedge \mathrm{r} /$

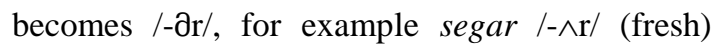
becomes seger /d/; putar (turn) becomes puter /ar/.

However, ikut (follow) becomes iko (delete consonant $/ \mathrm{t} /$ and change vowel $/ \mathrm{u} /$ becomes $/ \mathrm{o} /$. Second type is deleting the final sounds with only saying the initial sounds. For instance sudah (already) becomes su (delete /dah/), jangan (don't, not to) becomes jang (delete/ngan/). The third type is deleting the last sounds with changing vowels. The examples are punya (have) becomes pung (delete sound /nya/ and change /ny/ becomes /ng/).

\section{Impacts of Differences}

When we move from one place to another, the phenomenon is that we are deal with people who speak differently from us. One that belongs to one community will have similarities in pronouncing words or choosing the vocabulary that people used to speak every day. It is easy to recognize ones which do not belong to the society. However, Indonesia consists of multilingual 
and multicultural nations which consist of 742 languages with 737 languages that are still active and have the native language (Gordon, 2005 in Tondo, 2009). It means that language diversity is not something that separates the nations, but unity in diversity. That is the reason why Indonesian people can speak two or more vernacular languages simultaneously due to the dissimilar languages surround them. It is appreciated if one can speak more than one language since he/she can communicate easily with different society. Using the same vernacular language means showing solidarity in the society.

Problem can arise if no tolerant among the different language users, especially if they make fun the speakers of different vernacular language. Other hindrance if one community believe that their language is the dominant and underestimate other languages. If the dominant language speakers dictate the minorities, for example, it will lead to a conflict. Therefore Indonesian people need to be educated that we are big population in multilingual and multi culture that we should respect one another so that we can live in harmony.

\section{CONCLUSIONS}

We can communicate using informal Indonesian language in many places in Indonesia since it is the lingua franca for Indonesian people. If Bahasa is spoken differently in different places, it will enrich the informal dialects of Indonesian. The diversity affects good and bad sides. It provides good effect since Indonesia as multilingual nations can live peacefully and harmoniously. Differences in Indonesian dialects indicate that people from different place can communicate to each other even though each place provides different dialects which differ in choice of words (vocabulary), pronunciation, and intonation. Bad effects can occur if people just think that their 'dialect' is the best and do not want to collaborate with others. As a result, people from different dialect is considered the outsider or do not belong to their group. This can cause conflict when each group cannot accommodate differences. To avoid it, people need to be educated that Indonesia consists of numerous languages and dialects which also means various cultures. They need to be taught to be tolerant to other cultures. Every culture and language has its own uniqueness but none is better than others or none is worse than others. On the other side, differences in pronouncing informal Indonesian words can trigger verbal bullying if people move to other place in Indonesia with different dialect. They can be victims of verbal bullying so that people can make fun of those with different dialects.

\section{REFERENCES}

[1] Alptekin, C., 1993. Target-language culture in EFL materials. ELT journal, 47(2), pp.136-143.

[2] Brown, H.D., 2000. Principles of language learning and teaching.

[3] Creswell, J. W., \& Poth, C. N. (2017). Qualitative inquiry and research design: Choosing among five approaches. Sage publications.

[4] Dharma, A. (2011). Pembinaan dan Pengembangan Bahasa Daerah.

[5] Jiang, W., 2000. The relationship between culture and language. ELT journal, 54(4), pp.328-334.

[6] Nasir, M. (2003). 3.1 Metode Penelitian.

[7] Rohmitriasih, M. 2018. Serupa tapi tak sama, ini perbedaan ketupat, lontong dan buras. https://www.fimela.com/lifestylerelationship/read/3679962/serupa-tapi-tak-samaini-perbedaan-ketupat-lontong-dan-buras

[8] Tondo, H. (2009). Kepunahan bahasa-bahasa daerah: Faktor penyebab dan implikasi etnolinguistis. Jurnal Masyarakat dan Budaya, 11(2), 277-296 